\title{
A new species of Proctophyllodes Robin, 1868 (Acari: Proctophyllodidae) from two tanagers of the genus Piranga Vieillot (Passeriformes: Cardinalidae) from North America
}

\author{
Fabio Akashi Hernandes, Barry M. OConnor, Gary R. Bauchan \& Ronald \\ Ochoa
}

To cite this article: Fabio Akashi Hernandes, Barry M. OConnor, Gary R. Bauchan \& Ronald Ochoa (2017) A new species of Proctophyllodes Robin, 1868 (Acari: Proctophyllodidae) from two tanagers of the genus Piranga Vieillot (Passeriformes: Cardinalidae) from North America, Journal of Natural History, 51:41-42, 2407-2416, DOI: 10.1080/00222933.2017.1381772

To link to this article: https://doi.org/10.1080/00222933.2017.1381772

Published online: 05 Oct 2017.

Submit your article to this journal $\pi$

山 Article views: 58

View Crossmark data \lceil

Citing articles: 1 View citing articles ¿ð 


\title{
A new species of Proctophyllodes Robin, 1868 (Acari: Proctophyllodidae) from two tanagers of the genus Piranga Vieillot (Passeriformes: Cardinalidae) from North America
}

\author{
Fabio Akashi Hernandes ${ }^{\mathrm{a}}$, Barry M. OConnor ${ }^{\mathrm{b}}$, Gary R. Bauchan ${ }^{\mathrm{c}}$ and Ronald Ochoad

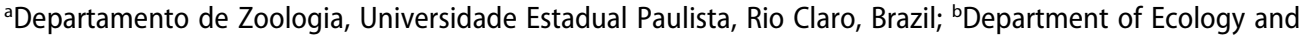 \\ Evolutionary Biology, Museum of Zoology, University of Michigan, Ann Arbor, MI, USA; 'Electron and \\ Confocal Microscopy Unit, US Department of Agriculture, Beltsville Agricultural Research Center, Beltsville, \\ MD, USA; dSystematic Entomology Laboratory, US Department of Agriculture, Beltsville Agricultural \\ Research Center, Beltsville, MD, USA
}

\begin{abstract}
A new feather mite species, Proctophyllodes pirangae sp. n. (Acari: Proctophyllodidae) is described from two tanagers of the genus Piranga Vieillot, 1808 (Passeriformes: Cardinalidae) in North America: the Scarlet Tanager, Piranga olivacea (Gmelin) and the Western Tanager, Piranga ludoviciana (Wilson) (Passeriformes: Cardinalidae) from North America. The new species belongs to the anthi species group and differs from the most similar species, Proctophyllodes polyxenus Atyeo and Braasch, by having in males, the aedeagus and genital sheath extending to or slightly beyond the level of setae $g$, the anterior margin of the opisthogastric shield shallowly concave, and its posterior margin nearly squareshaped, and the lamellae smaller; in females, both the lobar cleft and the transverse band of soft tegument at level of setae $h 1$ are considerably narrower.
\end{abstract}

www.zoobank.org/urn:Isid:zoobank.org:pub:29B3D157-8114-48EC-AF31-61A99F6D0C3B

\section{ARTICLE HISTORY}

Received 18 April 2017

Accepted 13 September 2017

Online 5 October 2017

\section{KEYWORDS}

Feather mites; Acari; systematics; ectoparasites; avian mites

\section{Introduction}

The feather mite genus Proctophyllodes Robin (Acari: Astigmata: Proctophyllodidae) is the most species-rich genus of all feather mites, currently comprising about 175 species. Mites of this genus usually occur on the ventral side of vanes of the wing and tail feathers, and most species are associated with passerines (Passeriformes) (Atyeo and Braasch 1966; Mironov 2012, 2017; Mironov and OConnor 2014; Wang et al. 2014; Mironov et al. 2017). Despite also being found in most other proctophyllodine genera, such as Hadrophyllodes Atyeo, Hemipterodectes Berla, and Tanyphyllodes Atyeo, one of the most conspicuous characteristics of Proctophyllodes is the presence of a pair of lamellar projections at the rear end of males (Atyeo and Braasch 1966; Gaud and Atyeo 1996), which help in holding the couple together by increasing the surface area

CONTACT Fabio Akashi Hernandes abakashi@gmail.com @Departamento de Zoologia, Universidade Estadual Paulista, Rio Claro, São Paulo State, Brazil

๑ 2017 Informa UK Limited, trading as Taylor \& Francis Group 
in contact between the male and female during copulation, or between the male and the tritonymph in precopulatory guarding (Byers and Proctor 2014).

In the present paper a new species of Proctophyllodes is described from two species of tanagers (Passeriformes: Cardinalidae), the Scarlet Tanager, Piranga olivacea (Gmelin), from Maryland and Michigan (USA) and the Western Tanager, P. ludoviciana (Wilson) from Texas (USA) and Oaxaca (Mexico).

\section{Materials and methods}

The material was retrieved from three sources: (1) one male specimen of a Scarlet Tanager found by RO freshly roadkilled in the perimeters of the Beltsville Agriculture Research Center, west field, Maryland, USA and taken to the laboratory and kept in a freezer; (2) host specimens processed in the University of Michigan Museum of Zoology (UMMZ) and examined by BMOC before preparation; and (3) mite specimens in the collection of the late W.T. Atyeo, now housed in UMMZ. Mites were collected directly from the feathers under a stereoscope, cleared in $30 \%$ lactic acid for $24 \mathrm{~h}$ at $50^{\circ} \mathrm{C}$ or lactophenol at room temperature, and mounted in Hoyer's medium according to the standard technique for small acariform mites (Krantz and Walter 2009). After five days at $50^{\circ} \mathrm{C}$, the slides were sealed with varnish. Drawings and measuring of mites were made with a Leica DM3000 microscope equipped with differential interference contrast (DIC) optics and a camera lucida. Pencil sketches were scanned at $300 \mathrm{dpi}$ greyscale and line drawings were created with Adobe Illustrator CS6 and a Wacom Bamboo Create tablet. The chaetotaxy of the idiosoma and legs follows Griffiths et al. (1990) and Atyeo and Gaud (1966), respectively, with corrections for coxal setae proposed by Norton (1998). Measurements of particular structures are as described by Mironov and OConnor (2014).

Specimens from Maryland were observed using low temperature scanning electron microscopy (LT-SEM) following the technique described in Castro et al. (2015) and Hernandes et al. (2016). Type specimens are deposited at USNM - National Insect and Mite Collection, National Museum of Natural History, Smithsonian Institution, located at the SEL-USDA, Beltsville, Maryland, USA; UMMZ - Museum of Zoology, the University of Michigan (Ann Arbor, Michigan, USA); DZUnesp-RC - Collection of Acari of Department of Zoology of the Universidade Estadual Paulista, Rio Claro, São Paulo, Brazil.

\section{Family PROCTOPHYLLODIDAE Trouessart and Mégnin Subfamily PROCTOPHYLLODINAE Trouessart and Mégnin Genus Proctophyllodes Robin}

Type species: Dermaleichus glandarinus Koch (first included species)

Proctophyllodes pirangae Hernandes and OConnor sp. nov.

(Figures 1-4)

\section{Type material}

Holotype male, 12 male and 12 female paratypes ex Piranga olivacea (Gmelin) (Passeriformes: Cardinalidae), USA, Maryland, Prince George's Co., Beltsville, 30 April 


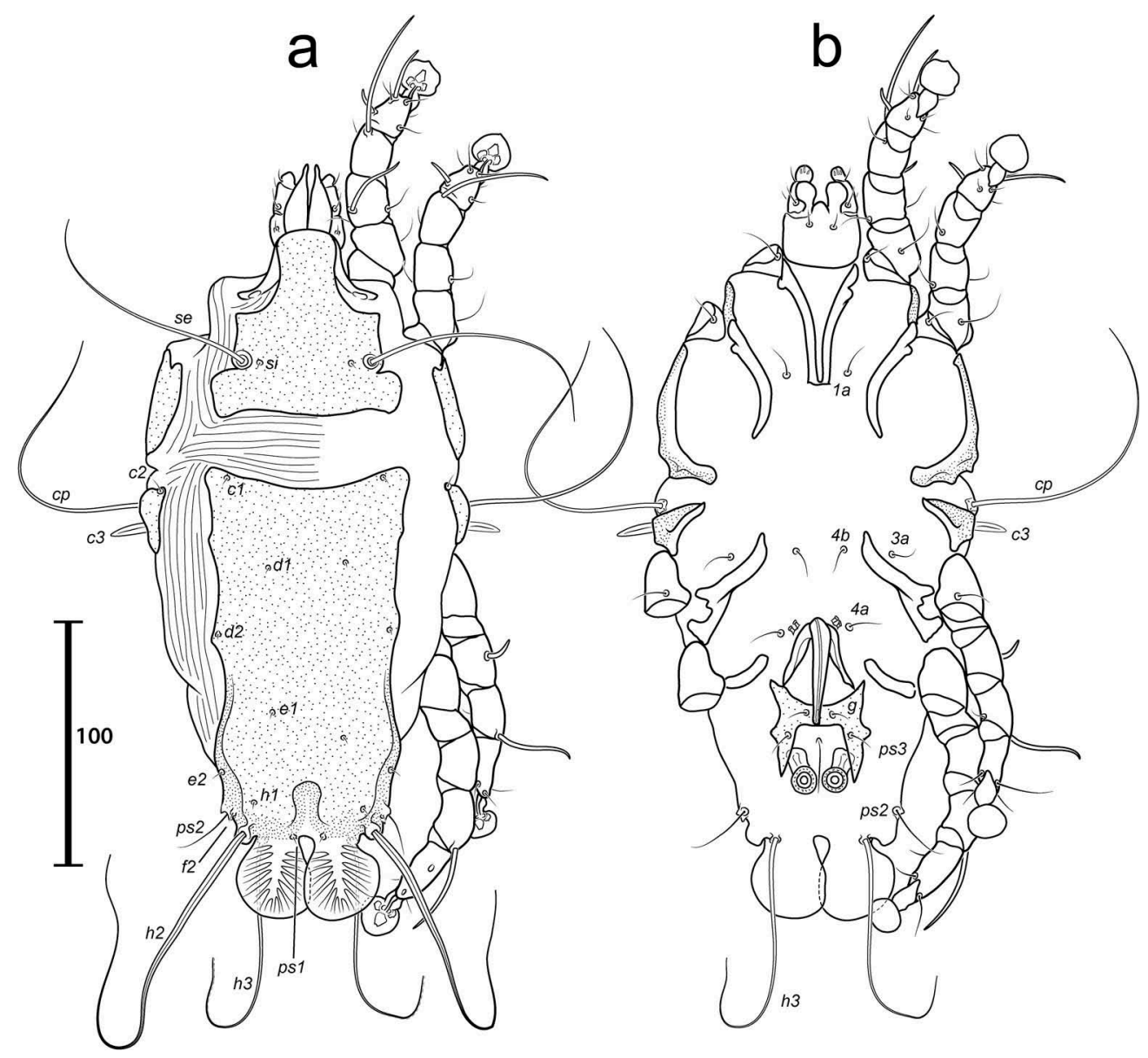

Figure 1. Proctophyllodes pirangae sp. nov., male. (a) Dorsal view, (b) ventral view.

2014, R. Ochoa coll.; Paratypes: 5 males, 5 females, (BMOC 86-0828-001) ex P. olivacea (UMMZ 224,850), USA: Michigan, Wayne Co., Plymouth, 42²0'N 8332'W, 10 May 1988, C. Guregian; 4 males, 6 females (BMOC 09-0803-001) ex P. olivacea (UMMZ 241,920), USA:

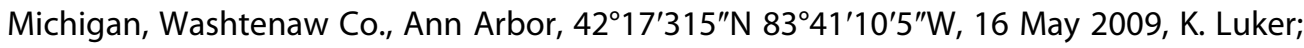
1 male, 4 females (BMOC 13-1101-001) ex P. olivacea (UMMZ 243,318), USA: Michigan, Washtenaw Co., Ann Arbor, University of Michigan campus, 42 ${ }^{\circ} 16^{\prime} 27^{\prime \prime} \mathrm{N} 83^{\circ} 44^{\prime} 00^{\prime \prime} \mathrm{W}, 24$ May 2013, L. Hawkes; 5 males, 6 females, (BMOC 09-1118-002) ex P. olivacea (UMMZ 241,960), USA: Michigan, Washteanw Co., $5.25 \mathrm{mi}$ SW Manchester, $42^{\circ} 05^{\prime} 50^{\prime \prime} \mathrm{N} 84^{\circ}$ $06^{\prime} 45^{\prime \prime}$, 12 May 2009, M. Bialecki.

\section{Additional material}

Three males, 2 females (BMOC 07-0213-005) ex Piranga ludoviciana (Wilson) (UMMZ 241,239), USA: Idaho, Ada Co., Boise area, no date, via Idaho Bird Observatory. Following specimens in collection of W.T. Atyeo, housed in UMMZ: 2 males, 2 females (NU 1852) ex P. Iudoviciana, USA: Texas, [Culberson Co.], Guadalupe Mountains, 27 April 1939, T.D. Burleigh; 2 males, 3 females (NU 1853) ex P. ludoviciana, MEXICO: Oaxaca, [Papaloapan 


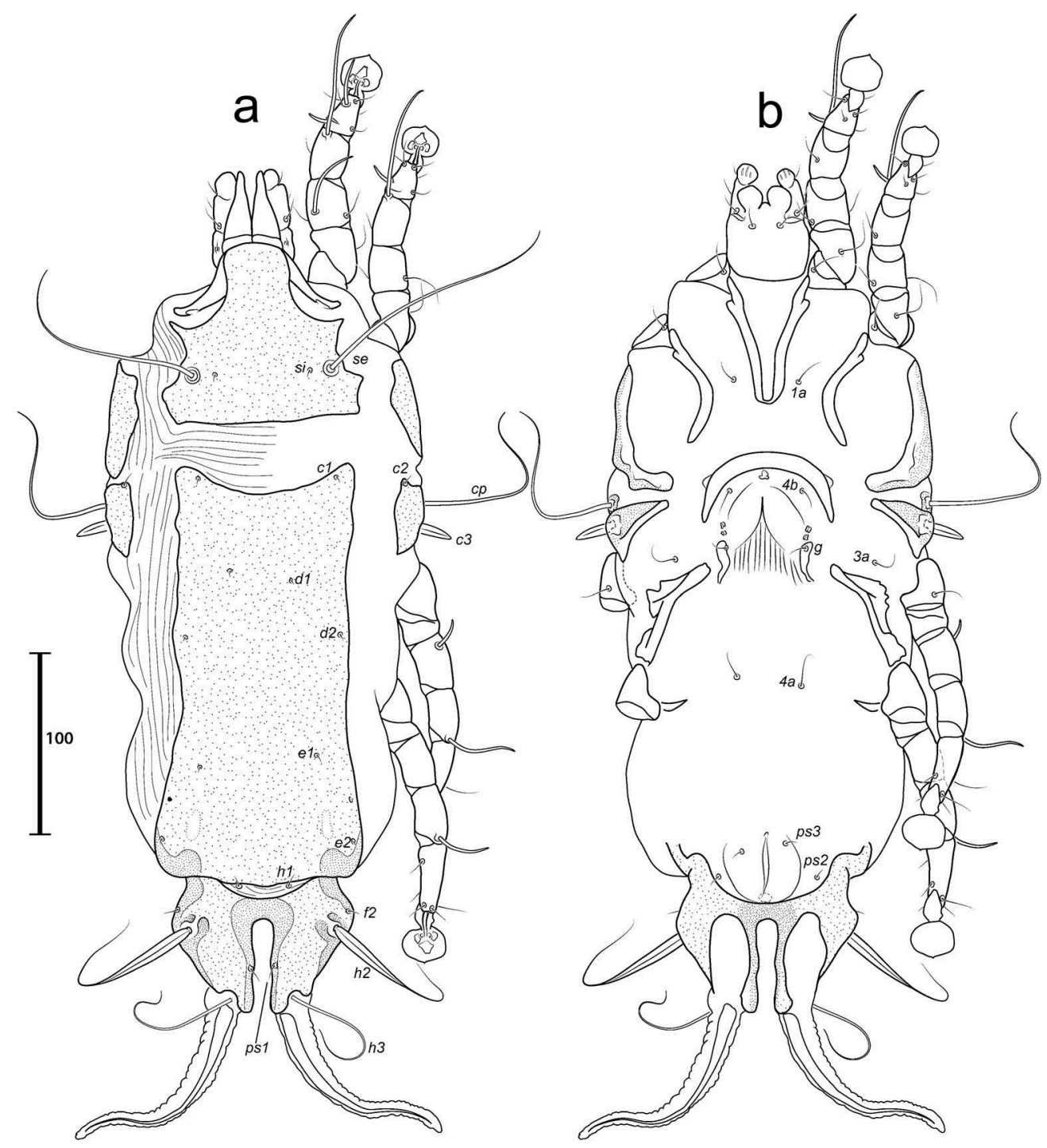

Figure 2. Proctophyllodes pirangae sp. nov., female. (a) Dorsal view, (b) ventral view.

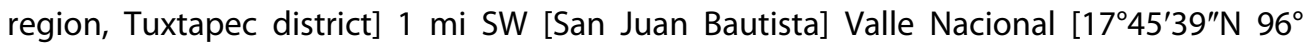
18'56"W], 1 April 1961, L.C. Binford. Note: The latter two collections were formerly identified by Atyeo and Braasch (1966) as Proctophyllodes polyxenus Atyeo and Braasch, 1966.

\section{Type deposition}

Holotype and paratypes at USNM; paratypes at UMMZ and DZUnesp-RC.

\section{Description}

Male. (Figures 1, 3(a-d, f), 4(d, f, g)); holotype, range for 8 paratypes in parentheses). Idiosoma, length $\times$ width, $246(228-250) \times 127(118-135)$; length of hysterosoma 149 


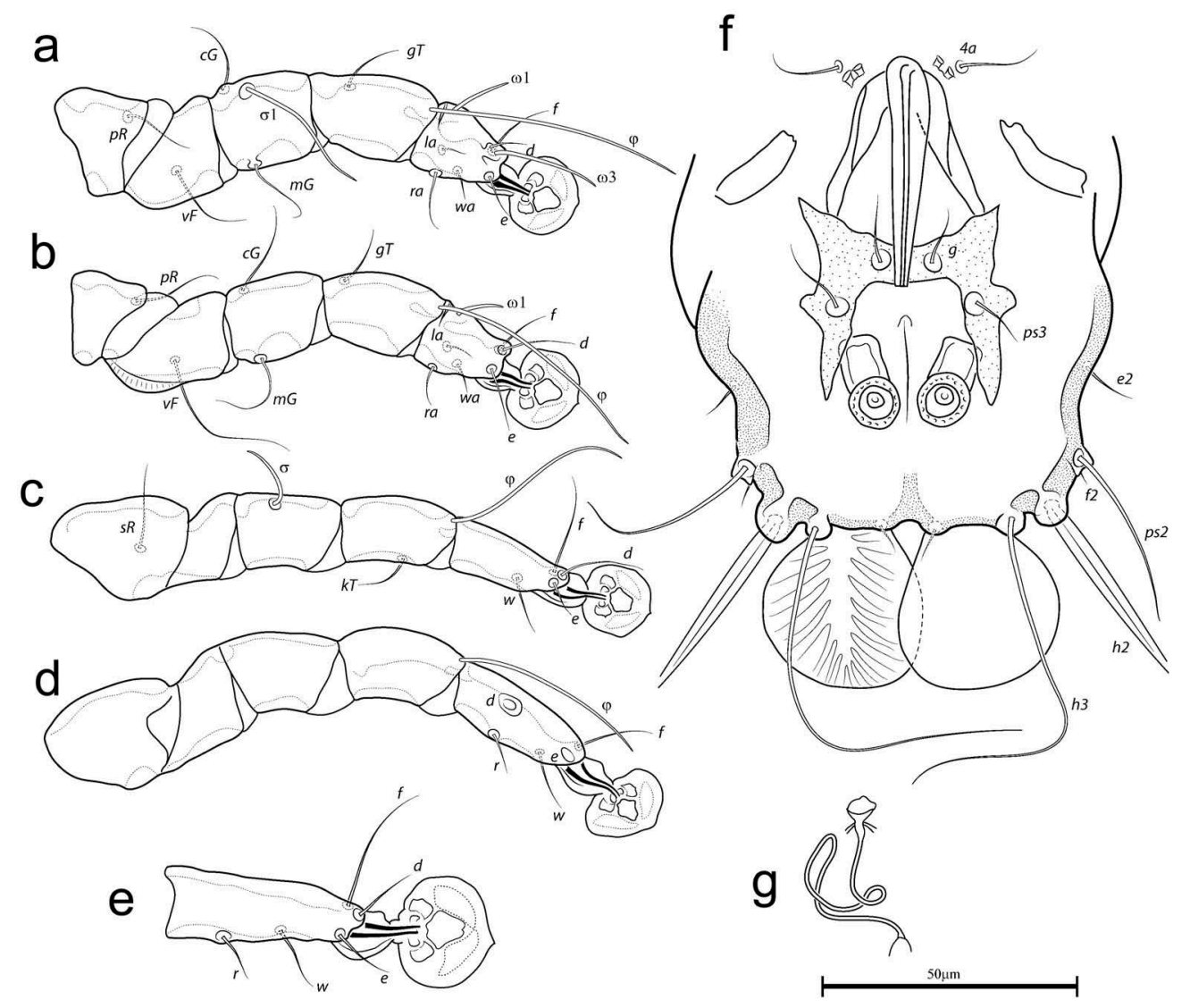

Figure 3. Proctophyllodes pirangae sp. nov.: (a-d) legs I-IV of male, (e) tarsus IV of female, (f) ventral view of male opisthosoma, $(\mathrm{g})$ female spermatheca.

(145-162). Prodorsal shield: setae vi absent, anterolateral extensions short, lateral margins entire, posterior margin sinuous, posterior angles truncate, greatest length 76 (64-77), greatest width 77 (67-80), surface without ornamentation. Distance between scapular setae se 53 (50-53). Scapular shields narrow. Humeral shields well-developed, not fused with epimerites III, setae c2 on anterior margins of humeral shields. Subhumeral setae $c 3$ lanceolate, 16 (16-18) in length, 4 (4) in width. Hysteronotal shield: anterior margin slightly concave, anterior angles rounded, length 148 (141-154), width at anterior margin 83 (75-83), surface without ornamentation. Supranal concavity open terminally, its anterior end between levels of setae $e 2$ and $h 1$, length from anterior end to bases of setae ps1 26 (25-34). Posterior margin of opisthosoma between setae $h 2$ almost straight. Terminal lamellae nearly circular, with inner margins slightly overlapping, with pennate venation; length 32 (29-44), greatest width 30 (26-37). Setae ps1 minute. Distances between hysteronotal setae: c2:d2 57 (53-64), d1:d2 27 (23-30), h1:h3 16 (12-15), h2:h2 53 (48-54), h3:h3 37 (34-37), ps2:ps2 64 (57-65).

Coxal apodemes I (epimerites) fused into a narrow $U$, without lateral extensions. Setae $4 b$ and $3 a$ situated at the same transverse level. Genital arch of moderate size, 29 (26-28) in length, 31 (25-31) in width, apex at posterior level of trochanters III, base situated at 

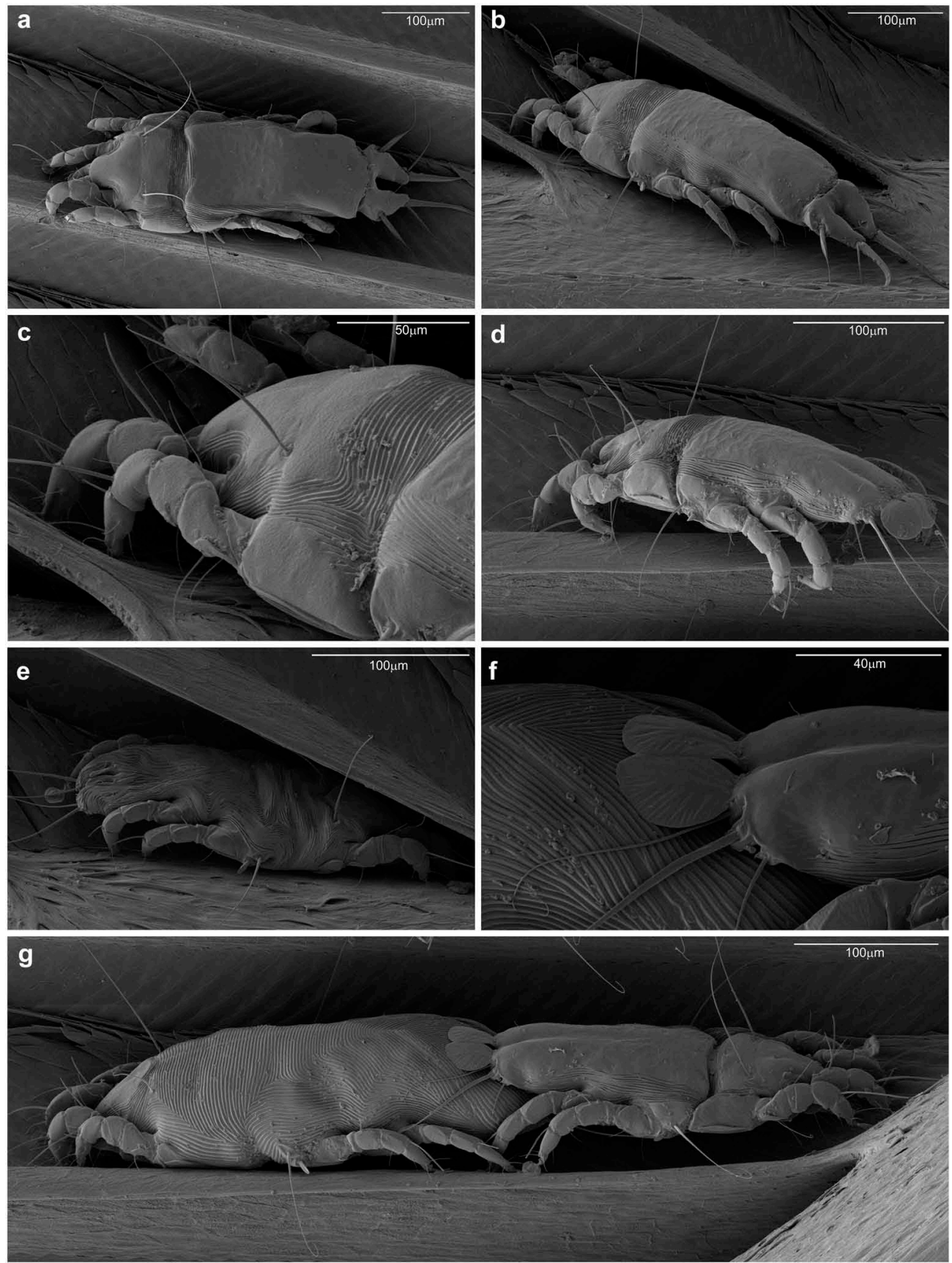

Figure 4. Proctophyllodes pirangae sp. nov. low temperature scanning microscope (LTSEM) pictures of: $(a-c)$ female, (d) male, (e) tritonymph, $(f-g)$ male attached to tritonymph in precopulatory guarding.

midlevel of trochanters IV. Aedeagus stylet-shaped, directed immediately backward from the genital arch apex, extending between levels of setae $g$ and $p s 3,43$ (39-43) in length; genital sheath wedge-shaped, extending to apex of aedeagus, slightly attenuate apically 
(Figures $1(\mathrm{~b}), 3(\mathrm{f})$ ). Setae $4 a$ situated at anterior level of the genital arch. Paragenital and pregenital apodemes absent. Bases of genital papillae connected. Opisthogastric shield $\mathrm{H}$-shaped with anterior arms touching the tips of genital arch, anterior ends with small and acute extension, with two small lateral projections at level of setae ps3; greatest length of opisthogastric shields 42 (38-44), greatest width in anterior part 39 (34-39). Setae $g$ and ps3 filiform, arranged in low trapezium, both setae on the opisthogastric shield, distances between these setae: g:g 10 (9-11), g:ps3 8 (7-9), and ps3:ps3 25 (2427). Adanal suckers cylindrical, 14 (17-21) in length, 8 (8-11) in width, corolla with 16-19 small teeth.

Femora II with narrow ventral crests. Tarsus IV 30 (27-31) in length, modified seta $d$ at basal third of this segment, noticeably larger than modified seta $e$ (Figure 3(d)). Genual solenidion $\sigma$ Ill slightly closer to basal margin of segment (Figure $3(\mathrm{c})$ ). Length of genual solenidia: $\sigma 1129$ (27-33) and olll 11 (11-14). Length of tibial solenidion $\varphi$ IV 35 (33-38).

Female. (Figures 2, 3(e, g), 4(a-c); range, for 8 paratypes): Length of idiosoma 398-423, width 161-178, length of hysterosoma 278-303. Prodorsal shield: setae vi absent, anterolateral extensions acute, lateral margins entire, posterior margin sinuous, length 91-100, width 101-111, surface without ornamentation (Figure 2(a)). Distance between scapular setae se 71-76. Scapular shields narrow. Humeral shields fused with epimerites III, encompassing bases of setae $c p$; setae $c 2$ on anterior margins of these shields. Subhumeral setae c3 lanceolate, 20-26 in length, 5-6 in width. Lobar region of opisthosoma separated from remaining part of hysterosoma, hysteronotal shield split into anterior and lobar parts by narrow transverse furrow, but remains connected ventrolaterally by sclerotized bands. Anterior hysteronotal shield roughly rectangular, 210-225 in length, 92-100 in width, with anterior margin concave, posterior margin sinuous, surface without ornamentation except for a pair of pale sclerotized areas near posterolateral margins. Lobar shield entire, anterior margin concave, 73-80 in length, 93-102 in width. Supranal concavity absent. Opisthosomal lobes attenuate apically; terminal cleft narrowly U-shaped, 46-53 in length, 11-15 in width at level of setae ps1. Setae $h 1$ on soft tegument between anterior hysteronotal and lobar shields. Setae $p s 1$ on lateral margins of terminal cleft. Setae $h 2$ with basal enlargement and with filiform apical part; setae $h 3$ filiform, 69-84 in length, about $3 / 4$ the length of terminal appendages. Distance between dorsal setae: c2:d2 76-85, h2:h3 34-40, d1:d2 30-37, h1:h2 22-27, h2:ps1 19-25, h1:h1 26-32, h2:h2 76-84.

Coxal apodemes I shaped as in males. Epigynum short, bow-shaped, tips nearly extending to level of genital papillae, lateral extensions absent, length 32-38, width 64-76. Copulatory opening situated immediately posterior to anal opening and covered with posterior ends of anal flaps (Figure 2(b)). Head of spermatheca simple, conical, secondary spermaducts short (Figure 3(g)). Translobar apodemes wide, connected to each other anterior to terminal cleft. Setae ps2 situated at basal half of anal opening and widely separated from each other.

Femur II with ventral crest as in male, femur I without crest. Solenidion $\sigma$ of genu III situated in basal part of segment. Length of genual solenidia: $\sigma 11$ 37-42 and olll 14-18. Length of tibial solenidia $\varphi \mathrm{IV}: 25-29$. Legs IV with ambulacral discs extending to level of setae $h 2$. 
Etymology. The species name is derived from the host genus and is a noun in the genitive case.

\section{Remarks}

The new species belongs to the anthi species group (Atyeo and Braasch 1966), which is characterized by having the following features: in males, genital organ not extending to level of setae ps3, the opisthogastric shield of each side broadly connected to the opposite member, and in contact with the genital arch; and both setae $g$ and ps3 inserted on the opisthogastric shields. The new species is most similar to Proctophyllodes polyxenus Atyeo and Braasch, 1966, from Passerella iliaca (Merrem) (Emberizidae) (type host) and reported from many other passerine hosts, by having in males the genital organ extending beyond the tips of genital arch, genital sheath relatively thick (wedge-shaped), lamellae not exceeding $60 \mu \mathrm{m}$, and in females terminal cleft more than $40 \mu \mathrm{m}$ in length, the lateral margins of the anterior hysteronotal shield normally sclerotized (not heavily dark), and supranal concavity absent. The new species differs from $P$. polyxenus by the following characteristics: in the male, the aedeagus and genital sheath extend to or slightly beyond the level of setae $g$, the anterior margin of the opisthogastric shield is shallowly concave, and its posterior margin is nearly squareshaped, and the lamellae are smaller (length $\times$ width $26-44 \times 26-37$ ). In females, the lobar cleft is considerably narrower, with length being about six times longer than the width, and the transverse band of soft tegument between the anterior and lobar shields is much narrower, occupying about half the opisthosomal width at level of setae $h 1$. In males of $P$. polyxenus, the aedeagus does not reach the level of setae $g$, both the anterior and posterior margins of the opisthogastric shield are semicircular, and lamellae length $\times$ width is $58 \times 42$ (range $60 \times 37$ in 3 paratypes); in females of $P$. polyxenus, the terminal cleft is much wider, with length about 1.8 times the width, and the transverse furrow between the anterior hysteronotal and lobar shields occupies almost the entire width at level of setae $h 1$, with these shields almost completely separated except for the lateral margins.

It is noteworthy to stress that the closest species $P$. polyxenus is unusual in host associations since it has been recorded on nearly 40 host species from five passerine families, including one species of the genus Piranga, P. ludoviciana (Wilson) (Cardinalidae), in addition to questionable records on three owl species (Atyeo and Braasch 1966). Those authors, however, acknowledged that this species might eventually be redefined as a species complex in future.

The genus Piranga was traditionally classified with the tanagers, family Tanagridae (Sclater 1886) or Thraupidae (AOU 1998) or Emberizidae, subfamily Thraupinae (Howard and Moore 1984). Dickinson (2003) regarded this genus as 'incertae sedis' along with some other tanager-like birds. Klicka et al. (2007) conducted a molecular phylogenetic analysis including Piranga and concluded that the genus belonged in the lineage treated as a tribe, Cardinalini, within an expanded concept of Emberizidae. Later workers have treated this lineage at the family rank, Cardinalidae (e.g. Bryson et al. 2013; Pulgarin-R et al. 2013). Eight species of Cardinalidae in this recent sense were known to harbour species of Proctophyllodes. These species, all described by Atyeo and Braasch (1966), have been placed in five different species groups (Mironov 2012). Four of these mite species are known from a single host genus or species: P. lordocaulus (weigoldi group), 
from Caryothraustes poliogaster (Du Bus de Gisignies), P. tricetratus (tricetratus group), from Spiza americana (Gmelin), P. habiae (weigoldi group) from Habia spp., and $P$. pheuctici (pinnatus group) from Pheucticus spp. The other two, P. longiphyllus (caulifer group) and $P$. polyxenus (anthi group), are both known from Cardinalidae and also hosts belonging to other families. To the extent that the host phylogeny is correct and the Proctophyllodes species groups are monophyletic (Klimov et al. 2017), this suggests extensive host shifts and colonization of different species of Cardinalidae rather than a long historical association of one lineage of Proctophyllodes and Cardinalidae.

\section{Acknowledgements}

This study was supported for FAH by the FAPESP - São Paulo Research Foundation (2011/501450 ). BMOC thanks Mrs Janet Hinshaw, collection manager of birds in UMMZ, for providing access to bird specimens being prepared for accession. To the NMNH- Smithsonian and SEL-USDA for help and support with references, equipment and material used in this study. Mention of trade names or commercial products in this publication is solely for the purpose of providing specific information and does not imply recommendation or endorsement by the USDA; USDA is an equal opportunity provider and employer.

\section{Disclosure statement}

No potential conflict of interest was reported by the authors.

\section{Funding}

This work was supported by the Fundação de Amparo à Pesquisa do Estado de São Paulo [2011/ 50145-0].

\section{References}

[AOU] American Ornithologists Union. 1998. Check-list of North American birds. Lawrence (KS): American Ornithologists Union; 829 p.

Atyeo WT, Braasch NL. 1966. The feather mite genus Proctophyllodes (Sarcoptiformes, Proctophyllodidae). Bull Univ Nebr Stat Mus. 5:1-354.

Atyeo WT, Gaud J. 1966. The chaetotaxy of sarcoptiform feather mites (Acarina: Analgoidea). J Kans Entomol Soc. 39:337-346.

Bryson RW Jr, Chaves J, Smith BT, Miller MJ, Winker K, Pérez-Emán JL, Klicka J. 2013. Diversification across the New World within the 'blue' cardinalids (Aves: Cardinalidae). J Biogeogr. 41(3):587599.

Byers K, Proctor HC. 2014. Like a glove: do the dimensions of male adanal suckers and tritonymphal female docking papillae correlate in the Proctophyllodidae (Astigmata: Analgoidea)? Acarologia. 54(1):3-14.

Castro EB, Ochoa R, Feres RJF, Beard J, Bauchan GR. 2015. Reinstatement of the genus Colopalpus Pritchard and Baker (1958) and re-description of Colopalpus matthyssei Pritchard and Baker (1958), the type species of the genus (Acari, Tenuipalpidae). Internat J Acarol. 41(4):310-328.

Dickinson EC, editor. 2003. The Howard and Moore complete checklist of the birds of the world. 3rd ed. Princeton (NJ): Princeton University Press; $1039 \mathrm{p}$.

Gaud J, Atyeo WT. 1996. Feather mites of the World (Acarina, Astigmata): the supraspecific taxa. Ann Mus Roy Afr Centr. Sér. In-8, Sces Zool. 277:1-193. (Pt. 1, text), 1-436 (Pt. 2, illustrations). 
Griffiths DA, Atyeo WT, Norton RA, Lynch CA. 1990. The idiosomal chaetotaxy of astigmatid mites. J Zool. 220:1-32.

Hernandes FA, Mironov SV, Bauchan GR, Ochoa R. 2016. A new asymmetrical feather mite of the genus Michaelia Trouessart, 1884 (Astigmata: Freyanidae) from the Neotropical cormorant, Phalacrocorax brasilianus (Pelecaniformes). Acarologia. 56(1):45-61.

Howard R, Moore A. 1984. A complete checklist of the birds of the world. Revised ed. London: Macmillan; $732 \mathrm{p}$.

Klicka J, Burns K, Spellman GM. 2007. Defining a monophyletic Cardinalini: a molecular perspective. Mol Phylogenet Evol. 45:1014-1032.

Klimov PB, Mironov SV, OConnor BM. 2017. Convergent and unidirectional evolution of extremely long aedeagi in the largest feather mite genus, Proctophyllodes (Acari: Proctophyllodidae): evidence from comparative molecular and morphological phylogenetics. Mol Phylogenet Evol. 140:212-224.

Krantz GW, Walter DE. 2009. A manual of acarology. 3rd ed. Lubbock: Texas Tech University Press; $807 \mathrm{p}$.

Mironov SV. 2012. New species of the feather mite genus Proctophyllodes Robin, 1877 (Acari: Analgoidea: Proctophyllodidae) from European passerines (Aves: Passeriformes), with an updated checklist of the genus. Acarina. 20(2):130-158.

Mironov SV. 2017. Two new feather mites of the genus Proctophyllodes Robin, 1868 (Acari: Proctophyllodidae) from European passerines (Aves: Passeriformes). Syst Parasitol. 94:215-226.

Mironov SV, Literak I, Sychra O, Capek M. 2017. Feather mites of the subfamily Proctophyllodinae (Acari: Proctophyllodidae) from passerines (Aves: Passeriformes) in Costa Rica. Zootaxa. 4297:1105.

Mironov SV, OConnor BM. 2014. New species of the feather mite family Proctophyllodidae (Acariformes: Astigmata) from two species of mockingbirds (Passeriformes: Mimidae) in Eastern North America. J Med Entomol. 51(3):529-546.

Norton R. 1998. Morphological evidence for the evolutionary origin of Astigmata (Acari: Acariformes). Exp Appl Acarol. 22:559-594.

Pulgarin-R PC, Smith BT, Bryson RW Jr, Spellman GM, Klicka J. 2013. Multilocus phylogeny and biogeography of the New World Pheucticus grosbeaks (Aves: Cardinalidae). Mol Phylogenet Evol. 69(3):1222-1227.

Sclater PL. 1886. Catalog of the Passeriformes or perching birds in the collection of the British Museum. Vol. XI. Fringilliformes: part II. London: Taylor \& Francis. 431 p +18 plates.

Wang Z, Wang J, Su X. 2014. Four new feather mite species of the genus Proctophyllodes Robin (Astigmata: Proctophyllodidae) from China. Zool Syst. 39(2):248-258. 